\title{
Geographically and environmentally driven spawning distributions of tuna species in the western Mediterranean Sea
}

\author{
P. Reglero ${ }^{1, *}$, L. Ciannelli ${ }^{2}$, D. Alvarez-Berasteguii ${ }^{3}$, R. Balbín ${ }^{1}$, J. L. López-Jurado ${ }^{1}$, \\ F. Alemany ${ }^{1}$ \\ ${ }^{1}$ Instituto Español de Oceanografía, Centre Oceanogràfic de les Balears, Moll de Ponent s/n, 07015 Palma de Mallorca, Spain \\ ${ }^{2}$ College of Earth, Ocean and Atmospheric Sciences, 104 CEOAS Administration Building, Oregon State University, \\ Corvallis, Oregon 97331-5503, USA \\ ${ }^{3}$ ICTS SOCIB — Sistema d'observació i predicció costaner de les Illes Balears. Parc Bit, Naorte, Bloc A 2-3, \\ Palma de Mallorca, Spain
}

\begin{abstract}
The spawning habitats of many large marine pelagic predators are poorly known. This lack of knowledge hampers conservation efforts that are aimed at identifying critical habitats for the spawning of these species. We hypothesized that phylogenetically related species show different adaptations and respond differently to environmental and geographical cues for when and where to spawn. We tested this hypothesis on a 5 yr data set (2001 to 2005) from the Balearic Islands region (Mediterranean Sea), targeting the early larval stage of 3 abundant species of tuna: bluefin tuna Thunnus thynnus, a large migratory oceanic species; albacore T. alalunga, a smaller species; and bullet tuna Auxis rochei, often found closer to coastal areas. The spatial distribution of spawning locations at the regional scale differed for the 3 tuna species. Bluefin tuna relied heavily on environmental signals, and therefore their spawning habitats can vary depending on the environment. In contrast, the spawning habitat of albacore and bullet tuna was driven mostly by geography and was less variable over contrasting environmental conditions. These regional adaptations for spawning habitats among the 3 tuna species may play a critical role in offspring survival and species interactions, and should be taken into account when establishing conservation practices.
\end{abstract}

KEY WORDS: Spawning strategy - Spawning habitat $\cdot$ Regional scale $\cdot$ Spatial distribution · Large predators $\cdot$ Migratory strategy $\cdot$ Mediterranean $\cdot$ Tuna

\section{INTRODUCTION}

The highest mortality rates in most marine organisms occur during their early life stages (McGurk 1986), so factors affecting the placement of eggs and the maturation of larval stages are critical aspects of a species' life history strategy. It is well established that in marine organisms, the adaptation to regional environments reflects adult responses for when and where to spawn that tend to optimize the offspring survival (Iles \& Sinclair 1982). However, the cost associated with reproductive activities, such as migration and gonad maturity, are also an important factor constraining the spawning locations of a species.

Many marine species undertake long migrations to reach their spawning grounds. Annual spawning migrations in temperate marine species are complex processes that result from the interactions among physiology, behavior, adult life history strategies, and larval ecology (Cury 1994, Corten 2001, Jørgensen et al. 2008). In contrast, other species have fairly restric- 
ted dispersal abilities and complete their life cycle in relatively closed spatial areas. It is possible that within similar geographical ranges, species with different life history traits can reproduce and thrive, but also show adaptations to local spawning habitats at smaller spatial scales.

The cues and clues that fish respond to in their decisions regarding when and where to spawn can be geographically and environmentally based (Bailey et al. 2004, Ciannelli et al. 2007). Some species may adapt to spawn in geographic areas where the environment tends to be more stable, and where habitat characteristics are optimal for the survival of later larval and juvenile stages. Other species may adapt toward a more opportunistic strategy and spawn within specific environmental ranges of a larger geographic area. Depending on the physical tolerances of the species, the 2 strategies can show any degree of mixing. At a regional spatial scale (e.g. around the Balearic Islands), the prevalence of one or the other spawning strategy can be correlated with specific life history traits. The important question then is how species' life history traits and spawning strategies are linked. Providing an answer to this question would allow us to generate hypotheses on how spawning strategies are regulated across a wide range of species, and thus to determine their importance in fisheries management decisions.

In this study, we were particularly interested in contrasting spawning strategies of closely related and spatially co-occurring species. We compared the degree to which spawning locations are either environmentally or geographically fixed in 3 species of tuna with contrasting life history strategies, but all spawning within the Balearic Islands region in the NW Mediterranean Sea. We focused our analyses on a larval tuna data set collected over 5 yr (2001 to 2005). The larva data cover a wide geographical scale $(180 \times 220$ nautical miles $)$ in the Balearic area of the Mediterranean Sea, where large spawning aggregations of tuna and other pelagic predator species are observed during spring and summer. The 3 tuna species that we investigated are Atlantic bluefin tuna Thunnus thynnus, Mediterranean albacore $T$. alalunga, and bullet tuna Auxis rochei. Part of the population of the large migratory Atlantic bluefin tuna comes from the Atlantic and crosses the Strait of Gibraltar to reach the Balearic Islands to spawn (Block et al. 2005, Rooker et al. 2008). This species is a large, oceanic temperate tuna. The Mediterranean albacore is a smaller tropical tuna that ranges widely in the Mediterranean Sea through its life cycle, but reproduces in large aggregations near the Balearic
Islands (Arrizabalaga et al. 2004). Adult bullet tuna, also a small tropical species, spawn and reside in more coastal locations (Sabatés \& Recasens 2001).

\section{MATERIALS AND METHODS}

The study area is the Balearic archipelago in the western Mediterranean basin. This area is characterized by the advection of new Atlantic water from the south that converges with northern resident Atlantic water, forming oceanographic structures such as fronts (Fig. 1). In summer, larval assemblages around the Balearic Islands show high proportions of the 3 tuna species examined in this study. The spatial distribution of spawning for these 3 selected tuna species was inferred from their early-larvae distributions. During June and July 2001 to 2005, tuna fish larvae were collected using a $333 \mu \mathrm{m}$ mesh fitted to $60 \mathrm{~cm}$ mouth opening Bongo nets that were equipped with flowmeters. Oblique tows were performed down to $70 \mathrm{~m}$ in the open sea or down to $5 \mathrm{~m}$ above the sea floor in shallower areas. Samples from the $333 \mu \mathrm{m}$ net were fixed with $4 \%$ formalin buffered with borax, and the larvae of the tuna species were further identified in the laboratory. Standard length (SL, mm) of all tuna larvae captured was measured without correction for shrinkage, and those identified as yolk sac and pre-flexion developmental stages (<4.5 mm) were merged into a class denominated 'stage-1.' Most studies using tuna larval data described spawning distribution for all developmental stages pooled together (Alemany et al. 2010, Muhling et al. 2010). The duration of the yolk-sac developmental stage in these larvae is very short (up to $1 \mathrm{~d}$, Margulies et al. 2007). Since dispersal mechanisms are important processes affecting the distribution of these early larval stages, we selected only the yolk-sac and the pre-flexion life stages. Around 200 stations located in a regular grid of $10 \times 10$ nautical miles were sampled every year (Table 1). This spatial resolution was chosen to take into account the patchy distribution of tuna species in the sampling (Alemany et al. 2010, Satoh 2010).

Among other hydrographic measurements, water temperature and salinity were recorded in situ at all stations using a CTD down to $350 \mathrm{~m}$ and at some deep stations down to $650 \mathrm{~m}$ (for more information on the variables measured, see Alemany et al. 2010). The geostrophic velocity (measured in $\mathrm{cm} \mathrm{s}^{-1}$ ) was estimated by differentiating the interpolated dynamic height field calculated from CTD measurements as described by Torres et al. (2011). 


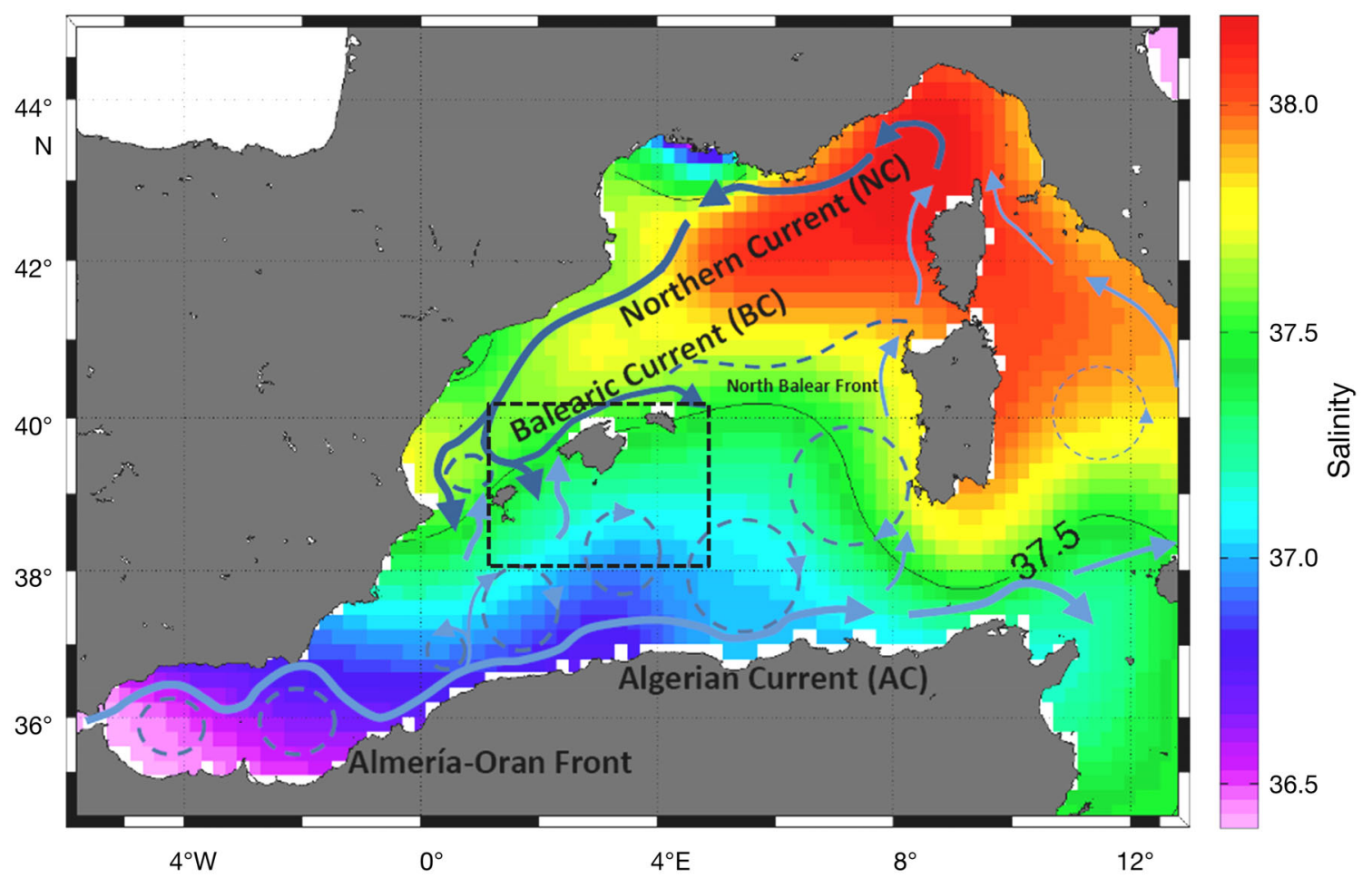

Fig. 1. Balearic Islands in the Mediterranean Sea, a primary spawning area for tuna species. The study area is identified by a black dashed square. Major currents are shown by the arrows: the Algerian current (AC, light blue solid line), the Northern current ( $\mathrm{NC}$, wide dark blue solid line), the Balearic current (BC, narrow dark blue solid line), the North Balear front (dark blue dashed line) and gyres (light blue dashed lines). The line for a salinity of 37.5 separating fresh Atlantic waters located to the south from resident Atlantic waters to the north is shown as a black line. Data for salinity obtained from MEDAR Group were averaged for July

We developed 2 nonparametric regression statistical models (generalized additive models, GAMs; Wood 2006) to assess (1) spatially varying patterns of spawning among the 3 species and (2) the importance of environmental variability in driving the locations for spawning. In all cases, the dependent variable was the number of stage-1 larvae of each species counted in the sample (Stage1). The covariates of the first GAM included latitude (lat) and longitude (lon) of the sampling stations to incorporate into the model the geographic effect, day of the year

Table 1. Auxis rochei, Thunnus alalunga, and T. thynnus. Number of stations where larvae of the 3 tuna species were found and total number of stations analyzed each year

\begin{tabular}{|ccccc|}
\hline Year & A. rochei & T. alalunga & T. thynnus & $\begin{array}{c}\text { No. stations } \\
\text { analyzed }\end{array}$ \\
\hline 2001 & 78 & 33 & 20 & 174 \\
2002 & 73 & 19 & 23 & 198 \\
2003 & 79 & 67 & 13 & 197 \\
2004 & 97 & 57 & 21 & 181 \\
2005 & 91 & 107 & 32 & 201 \\
& & & & \\
\hline
\end{tabular}

(cd) to address the timing of spawning, and hour of sampling (hour) to account for differences in larval catchability along the day cycle. GAMs based on these variables were used to describe geographical patterns in spawning alone, hereafter referred to as the 'geographical model.' The formulation of the geographical model was:

$$
\begin{aligned}
& \text { Stage } 1_{\text {species }}=a_{Y}+\text { offset }(\log (\text { vol }))+ \\
& \text { factor }(\text { year })+s_{1}(\text { lat,long })+s_{2}(\text { cd })+s_{3}(\text { hour })+\varepsilon
\end{aligned}
$$

where $s$ is either a 2-dimensional $\left(s_{1}\right)$ or a unidimensional $\left(s_{2-3}\right)$ smoothing function, typically a thin plate regression spline (Wood 2006), $a_{y}$ is a year-dependent model intercept, and $\varepsilon$ is the error. Due to the highly patchy nature of the abundances, we used an over-dispersed Poisson distribution to model larval data and a natural-log link. Volume of water filtered $\left(\mathrm{vol}, \mathrm{m}^{3}\right)$ was included as an offset (after natural log transformation), to account for the effort expanded in catching the sample. Sampling years were included as factors in the model to account for interannual variations of spawning output (related to spawning stock size). 
In the second model, we added hydrographical covariates to the geographical model, namely salinity, geostrophic velocity, and an index of water temperature. This model will be referred as the 'hydrographical model.' The selections of relevant hydrographical covariates were in part based on previous univariate analyses (Alemany et al. 2010) and in part based on minimizing cross-correlation among intervening variables. Salinity (Sal) was chosen because it is considered to be the best descriptor of the origin of water masses in the area (López-Jurado et al. 2008). Average salinities < 37.5 describe inflows of fresh Atlantic waters from the southern areas, whereas typical resident Atlantic waters described by average salinities $>37.5$ are usually located northwards (Fig. 1). The geostrophic velocity (Gvel) was included in the model since it is positively correlated with the intensity of the fronts due to the confluence of fresher and older Atlantic water in the channels. Because the temperature in the mixed layer (Temp) was strongly correlated with the sampling date, we estimated the temperature residuals against day of the year and position (lat and lon) using a GAM. As such, positive (negative) temperature residuals indicate locations where water temperature is above (below) average, given the location and time of the year.

The hydrographical model was formulated as:

Stage $1_{\text {species }}=a_{y}+\operatorname{offset}(\log (v o l))+$ factor $($ year $)+s_{1}($ lat,long $)+s_{2}(\mathrm{~cd})+s_{3}($ hour $)+$ $s_{4}(T e m p)+s_{5}(S a l)+s_{6}(G v e l)$
For both models, the variable selection criteria were based on the confidence region for the smooth effect, the $\mathrm{R}^{2}$, and the generalized cross validation (GCV) score (Wood 2006). GAMs were fitted using the 'mgcv' library in R statistical software (www. r-project.org).

\section{RESULTS}

We determined 3 spatially and environmentally separated spawning areas. Bullet tuna mostly spawn inshore in coastal areas surrounding the island of Mallorca, whereas albacore and bluefin tuna spawn offshore in eastern and southern areas, respectively (Fig. 2). Bullet tuna was the species most consistently found in specific geographic locations, followed by albacore and bluefin tuna, the latter of which showed the most variable spatial distribution (Table 1, Figs. 3 to 5). The spatial patterns were well captured by our best models in the 3 species for every year (Figs. 3 to 5). The spawning activity (as detected by the stage-1 larval abundance) had shorter duration for bluefin tuna than albacore and bullet tuna, whose duration was more protracted (Fig. 6a-c). The time of the day effect showed that the catchability of all tuna species increased during the night, but bluefin tuna also showed a peak around midday (Table 2, Fig. 6d-f).

Oceanographic conditions strongly constrained spawning of bluefin tuna compared to albacore and bullet tuna, whose spawning habitat was mostly
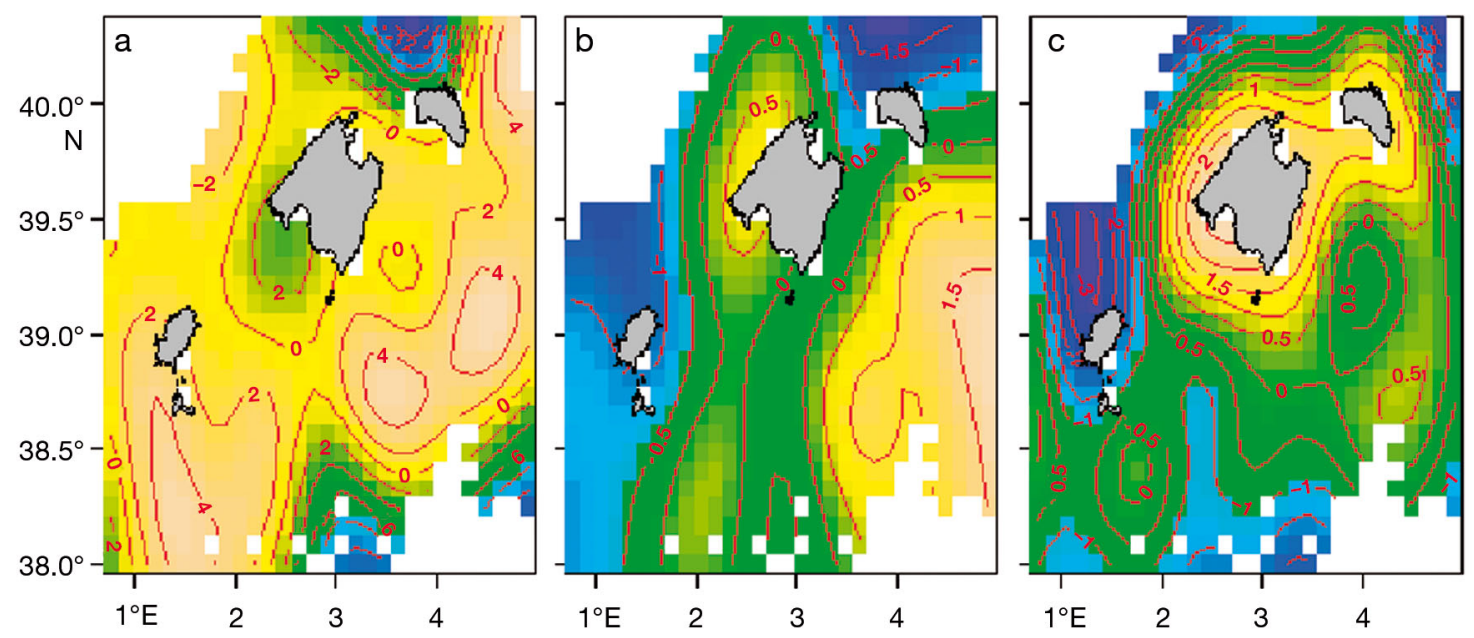

Fig. 2. Thunnus thynnus, T. alalunga, and Auxis rochei. Partial effects of position (latitude and longitude) on the abundance of (a) bluefin tuna, (b) albacore, and (c) bullet tuna as estimated from the geographical generalized additive model. Isolines indicate larval abundances predicted by the model. Peak of abundances are indicated in pink-yellow. Low and very low abundances are indicated in green and blue, respectively 


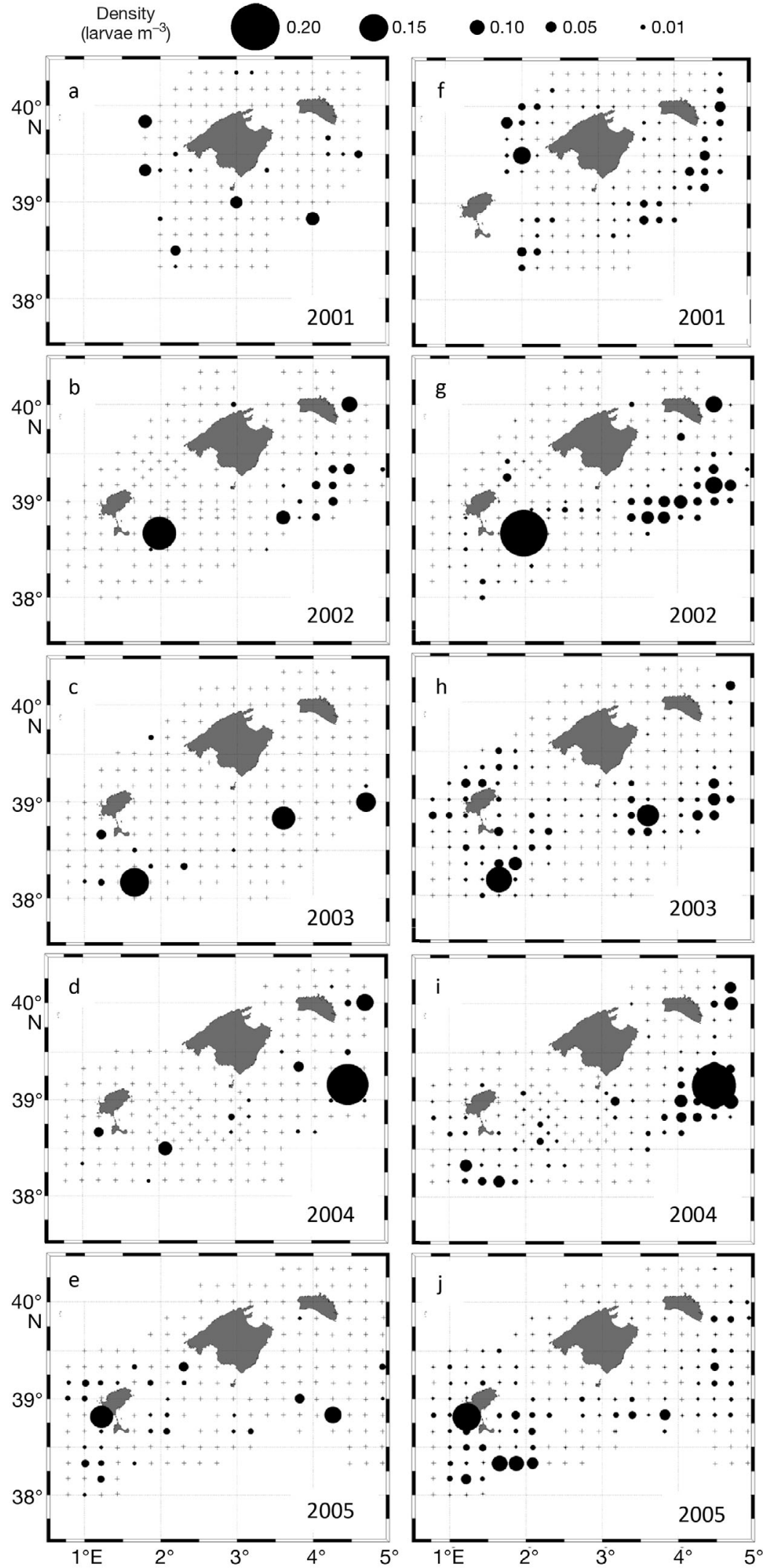

Fig. 3. Thunnus thynnus. (a-e) Observed and (f-j) predicted densities (larvae $\mathrm{m}^{-3}$ ) of bluefin tuna larvae for 2001 to 2005 related to the spatial position (Table 2). This result is inferred from the changes in percentage of explained variance after inclusion of hydrographical variables in the geographical model. For bluefin tuna, the explained variance changed from $37.3 \%$ in the geographical model (of which $<3 \%$ was explained by position alone, Table 2) to $75.3 \%$ in the total model. In contrast, the other 2 species had more contained changes of explained variance between geographic and total models $(15.4$ to $18.1 \%$ in albacore and 18.6 to $25.7 \%$ in bullet tuna). Bluefin tuna spawned in areas with intermediate salinities, where new and resident Atlantic waters converge, with a preference for areas with high frontal activity as shown from the positive relationship between bluefin tuna larval abundances and geostrophic velocity (Table 2, Fig. $7 \mathrm{a}-\mathrm{c}$ ). Temperature residuals had a significant effect only for bluefin tuna, with greater larval abundances at colder temperatures for a given location and time of the year. The best model fit for albacore was obtained for intermediate salinity and slow and intermediate geostrophic velocities, although the model improved little compared to the results obtained considering only geography (Table 2, Fig. 7d,e). For bullet tuna, there was a preference for low salinities and a positive linear relationship between the abundance of larvae and high geostrophic velocities, but still little improvement compared to the geographical model (Table 2, Fig. 7f,g). The distributions of the larval abundance for the 3 species in relation to background salinity and geostrophic velocities for 2001 to 2005 are shown in the supplement at www.int-res.com/articles/suppl/m463p 273_supp.pdf.

\section{DISCUSSION}

Our results indicated that aggregations of tuna species spawn in the same largescale area, but segregate their habitats at the regional scale based on the prevalence of either environmental or geographic preferences for their spawning habi- 


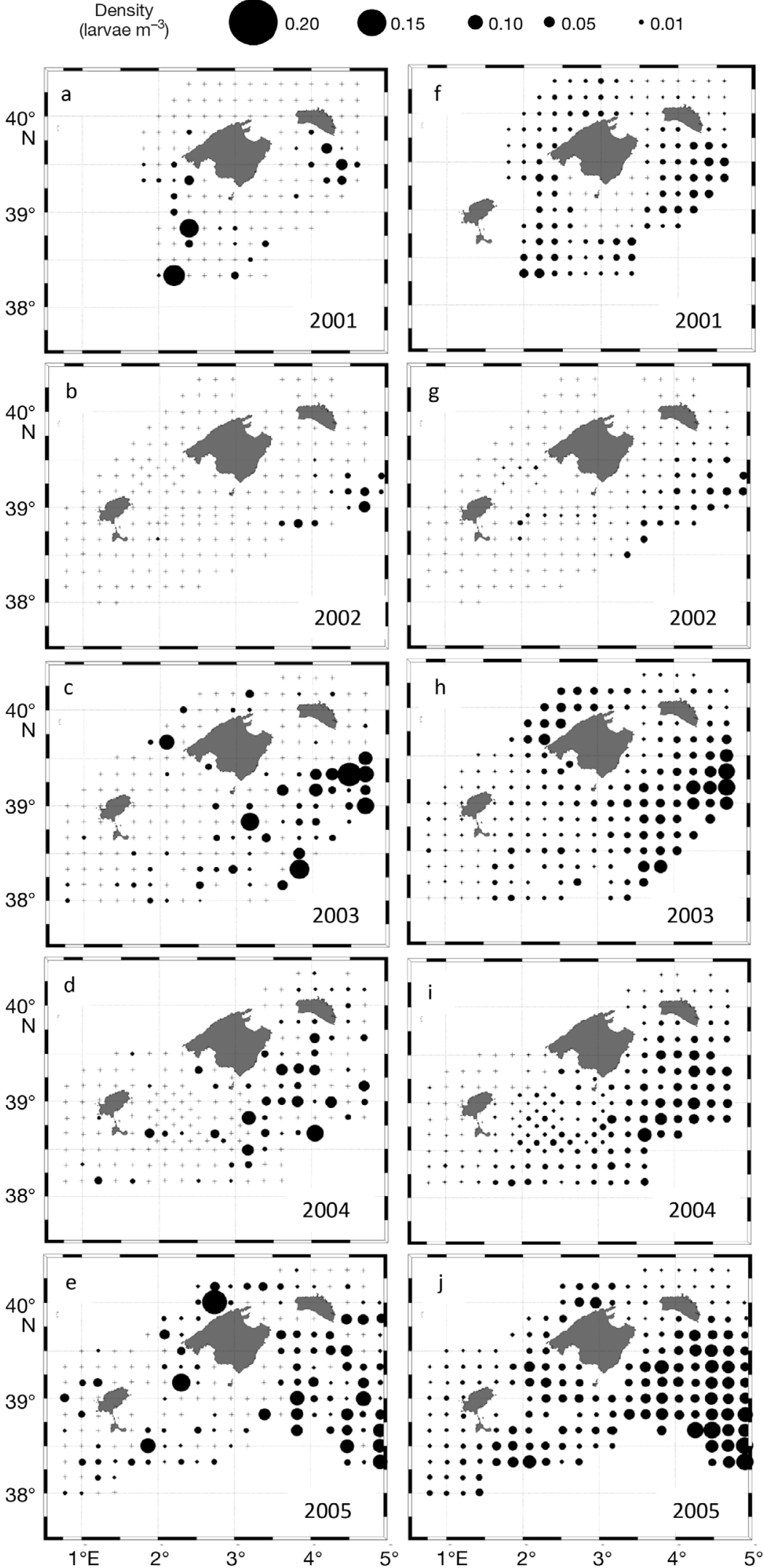

Fig. 4. Thunnus alalunga. (a-e) Observed and (f-j) predicted densities (larvae $\mathrm{m}^{-3}$ ) of albacore larvae for 2001 to 2005 tats. Therefore, spawning adaptation to changing environments and the mechanisms to maximize fitness may differ among tuna species. Descriptions of spawning habitats for tuna have focused on single species, mostly bluefin tuna, e.g. western Thunnus thynnus in the Gulf of Mexico (Teo et al. 2007, Muhling et al. 2010) and T. orientalis in Japan (Kimura et al. 2010, Kitagawa et al. 2010). Only 1 study compared habitat characteristics among tuna species using univariate models (Alemany et al. 2010). Our study built upon these previous ones by producing a comprehensive understanding of tuna spawning phenology and geography across phylogenetically close species and over different environmental variables. The species' life history traits may explain the observed temporal and spatial portioning of the spawning habitat at the regional scale. A conceptual representation of how the 3 different species of tuna that we targeted in our analysis split their spawning habitats is shown in Fig. 8 and is further discussed below.

\section{Portioning of temporal spawning}

We observed that bluefin tuna had a confined temporal schedule for spawning compared to albacore and bullet tuna. The prevalence of the time of spawning of bluefin tuna from mid-June to early July in the Balearic Islands has been well documented (Medina et al. 2002, Corriero et al. 2003). Albacore and bullet tuna can still occur in high densities later in the season (e.g. August) when bluefin tuna larvae are scarce (Alemany et al. 2006, Torres et al. 2011). This reproductive trait probably relates to the species-specific thermal tolerances with regard to spawning and larval survival. In general, tuna larvae have a narrower and warmer range of temperature preferences than the adults (Boyce et al. 2008), in turn suggesting that spawning habitats are more restricted than adult foraging grounds. Bluefin tuna follow a similar reproductive strategy (i.e. confined seasonal spawning) in different spawning regions (Kimura et 


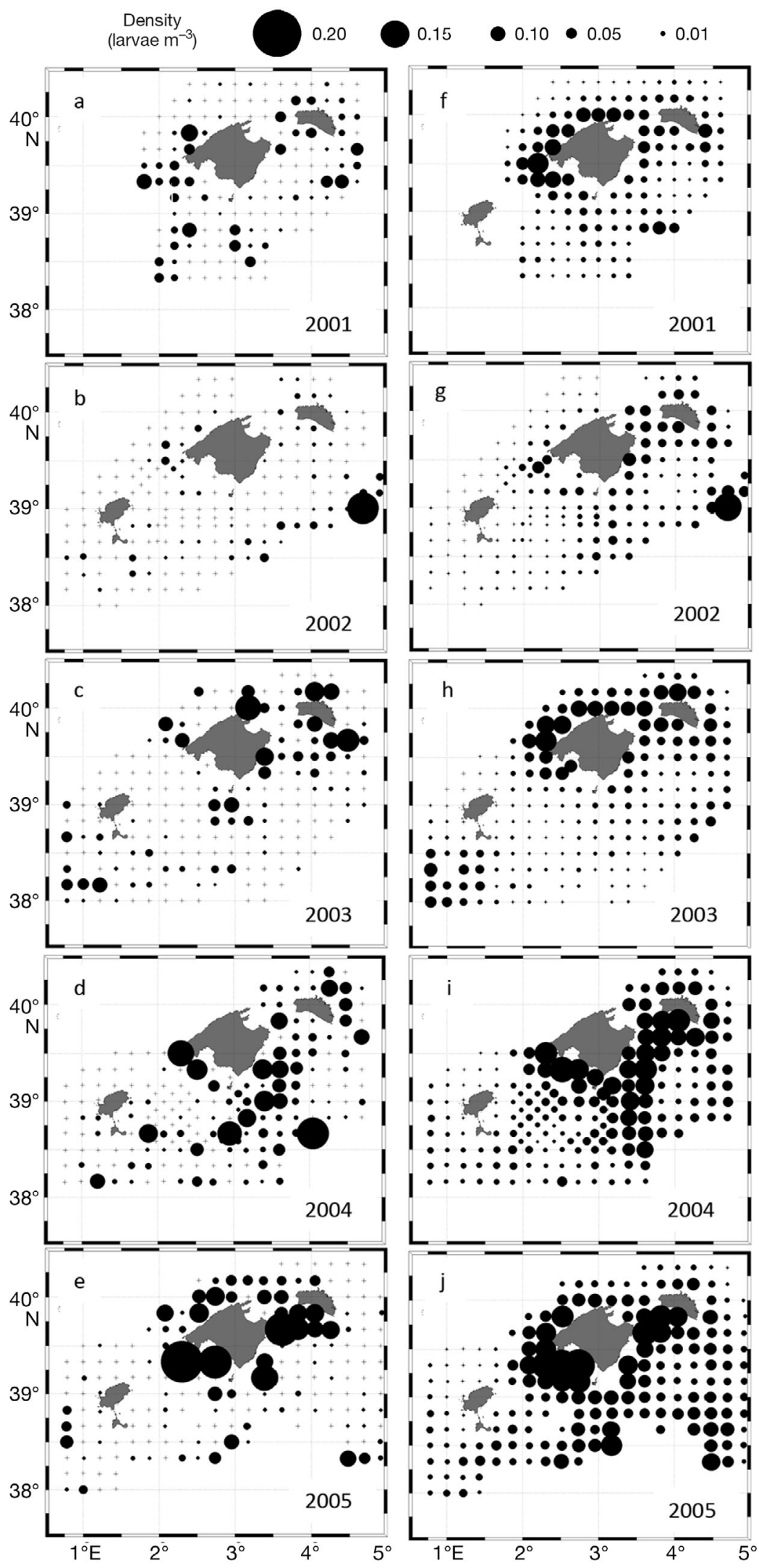

Fig. 5. Auxis rochei. (a-e) Observed and (f-j) predicted densities (larvae $\mathrm{m}^{-3}$ ) of bullet tuna larvae for 2001 to 2005 al. 2010). In comparison, albacore and bullet tuna can spawn year-round in tropical waters (Klawe 1963, Ahlstrom 1971, Nishikawa et al. 1985, Ramon \& Bailey 1996). No research has been conducted on the existing differences, if any, in the thermal tolerances of the larvae. Thus it is difficult to infer the degree to which physiological limitations determine the timing of spawning during the early life stages of the 3 species. Nevertheless, data from other temperate spawning areas support a wider temperature range for bullet tuna larvae than the other tuna species (Boehlert \& Mundy 1994, Muhling et al. 2010). The tropical nature of bullet tuna and albacore is reflected in our analyses, since the effect of temperature residuals was only significant for bluefin tuna, with a preference to spawn in the colder than average water temperatures; this result fits well with bluefin tuna adults, which are less tolerant of warm waters (Blank et al. 2004).

Adaptive behaviors for spawning time may act as regulators of other processes such as larval trophic interactions. The displacement of the spawning window of bullet tuna and albacore could be an adaptation to reduce the larval trophic interactions, thus increasing offspring success. Especially in low-productivity environments, larval growth and survival depend on maintaining a pure zooplankton diet, later changing to a piscivorous and cannibalistic diet (Reglero et al. 2011). If inter- and intraspecific predation among larvae are important, then bullet tuna and albacore could have evolved a more protracted spawning timing to avoid larval predation and to increase offspring survival.

Lastly, the confined temporal window of bluefin tuna could be an adaptation for the adults that spend energy migrating large distances from optimal foraging grounds in the Atlantic Sea. Bluefin tuna most probably use stored energy to develop the gonads (Medina et al. 2002). Their spawning events are sporadic, and the adults stay in the spawning ground no more than $2 \mathrm{wk}$, leaving soon thereafter (Gunn \& Block 2001, Medina et al. 2007), 

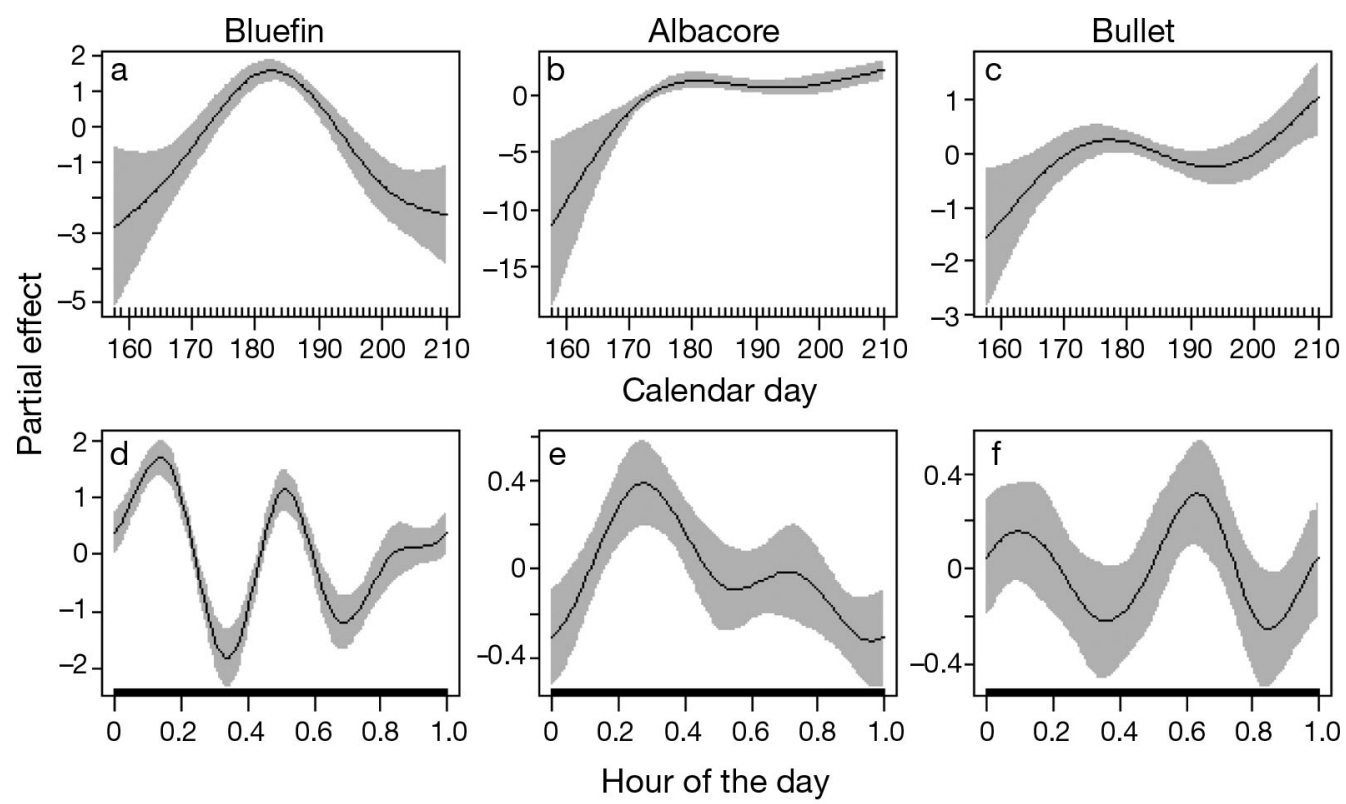

Hour of the day

Table 2. Thunnus thynnus, T. alalunga, and Auxis rochei. Geographical and total generalized additive models for 3 species of tuna. For each variable, we included the estimated degrees of freedom (indicative of departure from linearity), the probability, the $\mathrm{R}^{2}$, and the generalized cross validation (GCV) of a model that contains the described variable in addition to all of those preceding it in the table. See 'Materials and Methods' for a description of the variables

\begin{tabular}{|c|c|c|c|c|}
\hline $\begin{array}{l}\text { Species/model } \\
\text { Variable }\end{array}$ & df & $\mathrm{p}$ & $\begin{array}{c}\mathrm{R}^{2} \\
\text { cumulative }\end{array}$ & $\begin{array}{l}\text { GCV } \\
\text { score }\end{array}$ \\
\hline \multicolumn{5}{|l|}{ Bluefin tuna } \\
\hline lat, lon & 28.68 & $<0.0001$ & 2.88 & 5.54 \\
\hline$C d$ & 3.72 & $<0.0001$ & 13.1 & 4.88 \\
\hline Hour & 4.95 & $<0.0001$ & 37.3 & 4.07 \\
\hline Geographical & & & 37.3 & 4.07 \\
\hline sal & 3.84 & $<0.0001$ & 57 & 3.67 \\
\hline Gvel & 2.86 & $<0.0001$ & 62.4 & 3.47 \\
\hline $\operatorname{Tr}$ & 3.92 & $<0.0001$ & 75.3 & 3.09 \\
\hline Total model & & & 75.3 & 3.09 \\
\hline \multicolumn{5}{|l|}{ Albacore } \\
\hline lat, lon & 20.77 & $<0.0001$ & 12.3 & 4.03 \\
\hline$c d$ & 3.86 & $<0.0001$ & 14.3 & 3.84 \\
\hline Hour & 2.82 & $<0.001$ & 15.4 & 3.81 \\
\hline Geographical & & & 15.4 & 3.81 \\
\hline sal & 3.66 & $<0.0001$ & 16.1 & 3.75 \\
\hline Gvel & 3.56 & $<0.0001$ & 18.1 & 3.63 \\
\hline $\begin{array}{l}\operatorname{Tr} \\
\text { Total model }\end{array}$ & & No effect & 18.1 & 3.63 \\
\hline \multicolumn{5}{|l|}{ Bullet tuna } \\
\hline lat,lon & 26.78 & $<0.0001$ & 14.3 & 9.76 \\
\hline$c d$ & 3.44 & $<0.0001$ & 17.7 & 9.31 \\
\hline Hour & 4.06 & $<0.001$ & 18.6 & 9.15 \\
\hline Geographical & & & 18.6 & 9.15 \\
\hline sal & 3.62 & $<0.0001$ & 24.3 & 8.63 \\
\hline Gvel & 1 & $<0.0001$ & 25.7 & 8.53 \\
\hline $\operatorname{Tr}$ & & No effect & & \\
\hline Total model & & & 25.7 & 8.53 \\
\hline
\end{tabular}

most probably to foraging grounds located in the Atlantic (Block et al. 2005, Rooker et al. 2007). Migration distance may play a different role in albacore, since their feeding grounds are most likely located in the Mediterranean Sea where most of the population completes their entire life cycle (Arrizabalaga et al. 2004). However, migration trajectories within the Mediterranean for the 3 species are poorly known.

\section{Spatial portioning during spawning at the regional scale}

Adult eastern bluefin tuna follow the Atlantic waters to spawn in the Mediterranean, which explains the prevalence of the recently hatched larvae in the southern area of the islands where the newest Atlantic water encounters the more saline resident surface water. The other 2 main spawning areas in the Western-Central Mediterranean are located around Malta and the South Tyrrhenian Sea (Rooker et al. 2007), all receiving Atlantic water (Fig. 1). In the Balearic Islands, the position and activity of the fronts may act as a natural boundary that could be used by bluefin tuna adults as a signal to identify favorable spawning locations. Larger abundances of newly hatched albacore larvae in the northeast side of the Balearic Islands indicates spawning in surface waters with salinities above 37 and up to the maximum range, indicative of Atlantic water that has remained longer in the Mediterranean. For albacore, the dominant variable defining their spawning habitat was geographical position, 

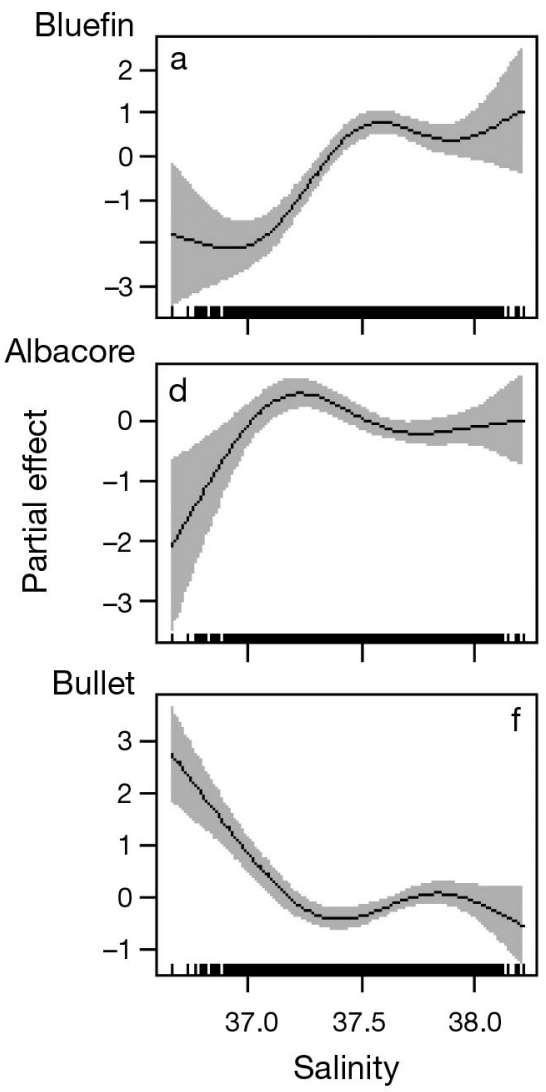
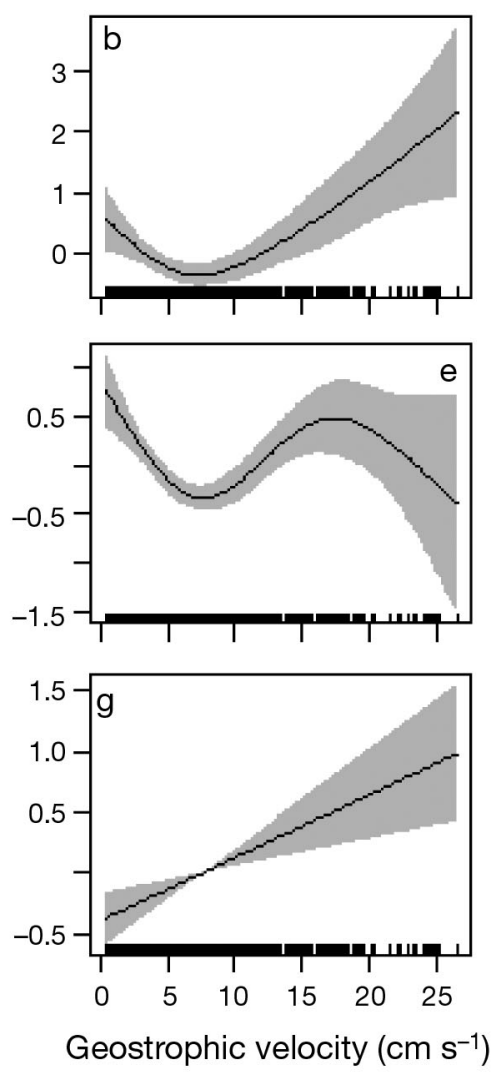

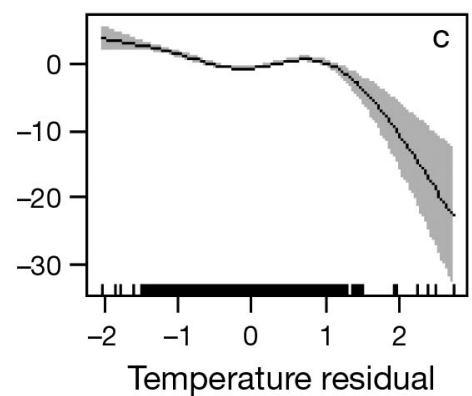

Fig. 7. Thunnus thynnus, T. alalunga, and Auxis rochei. Partial effects of significant environmental effects in the mixed layer (salinity, geostrophic velocity and temperature residual) on species abundance, as estimated from the hydrographical generalized additive model: $(\mathrm{a}-\mathrm{c})$ bluefin, $(\mathrm{d}, \mathrm{e})$ albacore and $(\mathrm{f}, \mathrm{g})$ bullet tuna. Other details as in Fig. 6

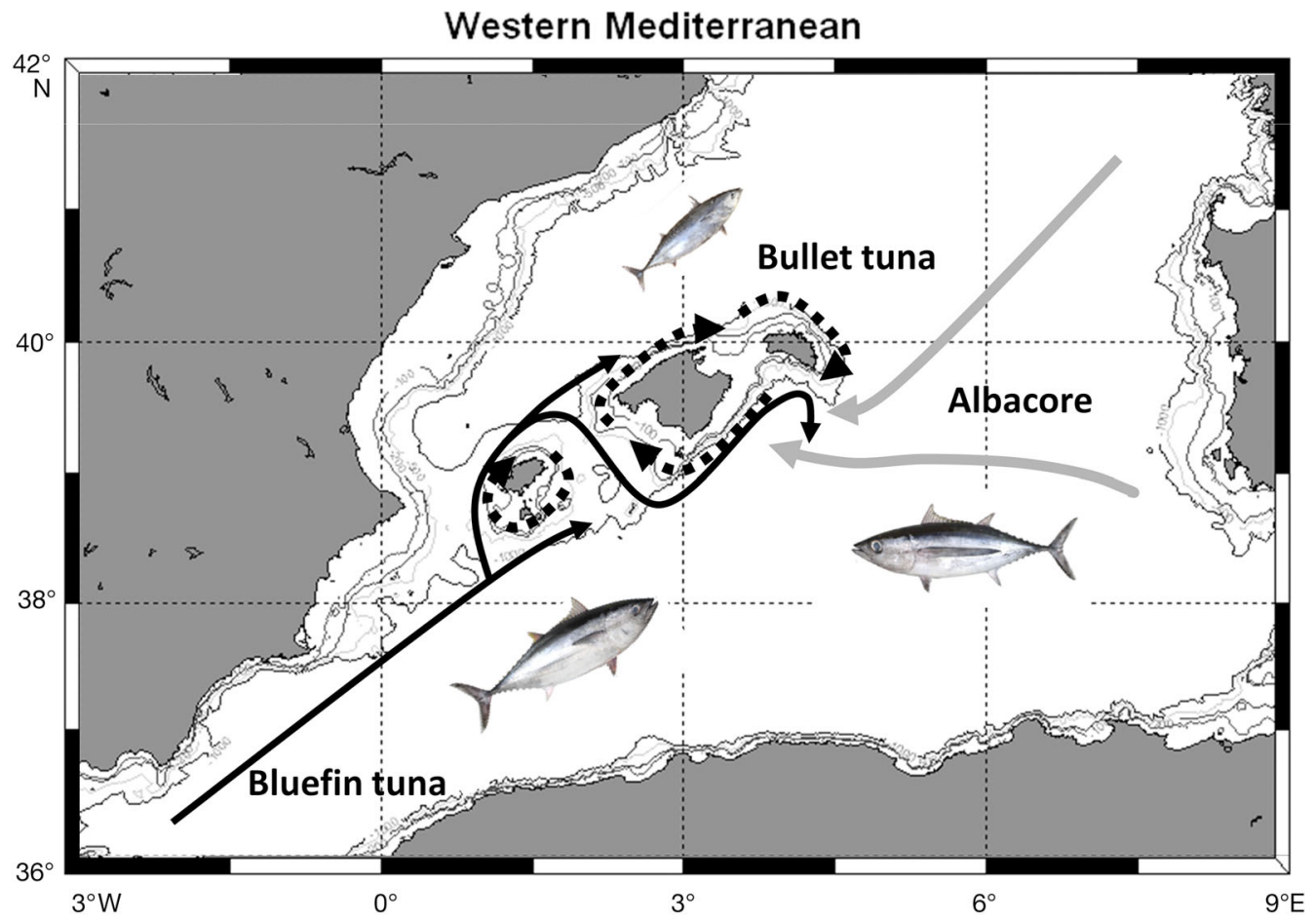

Fig. 8. Thunnus thynnus, T. alalunga, and Auxis rochei. Conceptual figure summarizing our results, showing the spawning geography of the 3 species of tuna associated with their plausible migration pattern, for the large migratory bluefin tuna (black solid line), the Mediterranean albacore (grey solid line), and the coastal bullet tuna (black dotted line). Tuna pictures from S. P. Iglésias 
resulting in consistent hotspots of larvae in locations to the north-east of the Balearic Islands. This area is situated northwards of a consistent hydrographic feature, viz. a topographically induced eddy associated with the islands. The eddy occurs every summer (J. L. López-Jurado pers. obs.) and could be used as a predictable signal for spawning. The more coastal location of adult bullet tuna (Sabatés \& Recasens 2001) fits well with the preference for coastal spawning areas. In contrast to albacore and bluefin tuna, large numbers of bullet tuna are also commonly found in coastal areas of the mainland, far from the islands (Morote et al. 2008), suggesting that spawning in this species is ubiquitously distributed in coastal areas.

The 3 species are iteroparous (spawning in several batches), asynchronous (having oocytes in all developmental stages), and indeterminate (new oocytes can develop in the female and be released during spawning) (Medina et al. 2002, Murua \& SaboridoRey 2003). The absolute fecundity is much lower in bullet tuna and albacore than in bluefin tuna due to their smaller size of the former, even though their rel-

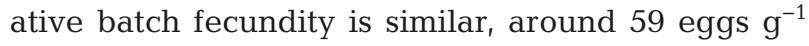
(Medina et al. 2007, Saber et al. 2011). Because of its large size, bluefin tuna can also store larger amounts of energy for reproduction and tolerate a broader range of environmental scenarios (Sharp 2001, Medina et al. 2002) than the other 2 species. This favors an opportunistic spawning behavior following specific environmental signals indicating that conditions are optimal.

Environmentally-driven spawning has been observed in bluefin tuna in other areas at a regional scale. Atlantic bluefin tuna belonging to the so-called Western stock migrate long distances to breed close to mesoscale structures in the Gulf of Mexico (Teo et al. 2007).On the other hand, short distance migrants or species with limited home ranges are limited in their opportunities to disperse during early life stages, since water parcels with retention features are typically located near bathymetric features (e.g. banks, capes, sills in fjords). This strategy will ensure self recruitment, probably at a more regional scale in albacore, spawning offshore in geographically fixed areas driven by predictable and consistent oceanographic features, and at a more local scale in bullet tuna, spawning adjacent to the coast. In Mallorca, the coastal morphology and wind forcing favors local recruitment of fish species inhabiting very coastal habitats (Basterretxea et al. 2012), a mechanism that may apply to bullet tuna as well at a larger spatial scale.

\section{Spawning strategies and capacities for adaptation to changing environments}

Species responding to environmental cues shift their spawning distribution over contrasting environmental regimes, while species that respond to geographical cues will be less likely to change their spawning distribution in the face of underlying environmental changes. Bluefin tuna are opportunistic spawners that follow environmental signals and adapt to year-to-year or longer-time variability. A major physiological constraint for bluefin tuna during spawning is the lower tolerance for warm waters, mainly in larger fish (Blank et al. 2004). This may become an important limitation if the average surface temperatures increase in the Mediterranean Sea. If the reproductive success of tuna in the area is related to the coexistence of different developmental stages of tuna species, then different phenological responses among the 3 species to the environment influencing their timing and spatial spawning may influence their recruitment. On the other hand, migration constraints for the smaller-sized bullet tuna and albacore will limit expansion to new spawning habitats if these species are faced with environments less suitable for their larvae. Better knowledge of larval physiology and migration patterns are key to improving our understanding of the capacity for adaptation to changing environments in these species.

\section{Implications for management}

Differences among the 3 species in their spawning strategies can play an important role for tuna conservation and management in the region. Currently, the major commercial fishery of tuna in the Mediterranean Sea consists of purse seiners explicitly targeting aggregations of reproductive eastern bluefin tuna adults (Fromentin \& Powers 2005). Reproductive albacore and bullet tuna are also caught as by-catch or are targeted by traditional and recreational fisheries (ICCAT 2011). During the last decades, there has been a decreasing trend in eastern bluefin tuna spawning stock biomass (ICCAT 2008). Since spawning adults are the bulk of the fishery, temporal and/or spatial management measures such as closures to protect spawners, in addition to total allowable catch quotas already implemented, could be used as a strategy to manage and restore tuna populations. The information herein on the species' reproductive traits is fundamental for spawning area closures to be 
implemented successfully, a management option that has been described as biologically and economically efficient in other tuna stocks (Armsworth et al. 2010). Nowcasts and short-term forecast operational decisions including our results, that provide insights into the spawning habitat distributions of tuna species, could be a valuable tool for tuna conservation in the region (Hobday et al. 2011).

Acknowledgements. We thank the scientists and crew participating in the TUNIBAL cruises. $\varnothing$. Fiksen and K. Bailey helped with valuable comments. We thank 3 anonymous reviewers for their comments on the original version of the manuscript. This study was funded by the Spanish Institute of Oceanography, the Spanish Ministry of Science (BALEARES, 2009-07944 MAR), and the ICTS-SOCIB (Bluefin project). A research stay of L.C. was supported by a UIB scholarship and ICTS-SOCIB. L.C. acknowledges further support from NSF-CMG grant 0934961.

\section{LITERATURE CITED}

Ahlstrom EH (1971) Kinds and abundance of fish larvae in the eastern tropical Pacific based on collections made on Eastropac 1. Fish Bull 69:1-77

Alemany F, Deudero S, Morales-Nin B, López-Jurado JL, Jansá J, Palmer M, Palomera I (2006) Influence of physical environmental factors on the composition and horizontal distribution of summer larval fish assemblages off Mallorca island (Balearic archipelago, western Mediterranean). J Plankton Res 28:473-487

Alemany F, Quintanilla L, Velez-Belchi P, Garcia A and others (2010) Characterization of the spawning habitat of Atlantic bluefin tuna and related species in the Balearic Sea (western Mediterranean). Prog Oceanogr 86:21-38

Armsworth PR, Block BA, Eagle J, Roughgarden E (2010) The economic efficiency of a time-area closure to protect spawning bluefin tuna. J Appl Ecol 47:36-46

Arrizabalaga H, Costas E, Juste J, González-Garcés A, Nieto B, López-Rodas V (2004) Population structure of albacore Thunnus alalunga inferred from blood groups and tagrecapture analyses. Mar Ecol Prog Ser 282:245-252

Bailey KM, Hollowed AB, Wooster WS (2004) Complexity in marine fisheries dynamics and climate interactions in the Northeast Pacific Ocean. In: Stenseth NC, Ottersen G, Hurrel JW, Belgrano A (eds) Marine ecosystems and climate variation. Oxford University Press, Oxford, p 147-152

Basterretxea G, Jordi A, Catalán IA, Sabatés A (2012) Model-based assessment of local-scale fish larval connectivity in a network of marine protected areas. Fish Oceanogr in press 21:291-306

> Blank JM, Morrisette JM, Landeira-Fernández AM, Blackwell SB, Williams TD, Block BA (2004) In situ cardiac performance of Pacific bleufin tuna hearts in response to acute temperature change. J Exp Biol 207:881-890

Block BA, Stevens ED, Teo SLH, Walli A and others (2005) Electronic tagging and population structure of Atlantic bluefin tuna. Nature 434:1121-1127

Boehlert GW, Mundy BC (1994) Vertical and onshoreoffshore distributional patterns of tuna larvae in relation to physical habitat features. Mar Ecol Prog Ser 107:1-13
Boyce DG, Titterson DP, Worm B (2008) Effects of temperature on global patterns of tuna and billfish richness. Mar Ecol Prog Ser 355:267-276

> Ciannelli L, Bailey KM, Chan KS, Stenseth NC (2007) Phenological and geographical patterns of walleye pollock (Theragra chalcogramma) spawning in the western Gulf of Alaska. Can J Fish Aquat Sci 64:713-722

Corriero A, Desantis S, Deflorio M, Acone F and others (2003) Histological investigation on the ovarian cycle of the bluefin tuna in the western and central Mediterranean. J Fish Biol 63:108-119

> Corten A (2001) The role of 'conservatism' in herring migrations. Rev Fish Biol Fish 11:339-361

> Cury P (1994) Obstinate nature: an ecology of individuals. Thoughts on reproductive behavior and biodiversity. Can J Fish Aquat Sci 51:1664-1673

> Fromentin JM, Powers JE (2005) Atlantic bluefin tuna: population dynamics, ecology, fisheries and management. Fish Fish 6:281-306

Gunn J, Block B (2001) Advances in acoustic, archival, and satellite tagging of tunas. In: Block BA, Stevens ED (eds) Tuna: physiology, ecology and evolution. Academic Press, London, p 167-224

Hobday AJ, Hartog JR, Spillman CM, Alves O (2011) Seasonal forecasting of tuna habitat for dynamic spatial management. Can J Fish Aquat Sci 68:898-911

ICCAT (International Commission for the Conservation of Atlantic Tunas) (2008) Report of the 2008 Atlantic bluefin tuna stock assessment session. Collect Vol Sci Pap ICCAT 64:1-352

ICCAT (2011) Report of the 2010 ICCAT Mediterranean albacore data preparatory meeting. Collect Vol Sci Pap ICCAT 66:1809-1856

Iles TD, Sinclair M (1982) Atlantic herring: stock discreteness and abundance. Science 215:627-633

Jørgensen C, Dunlop ES, Opdal AF, Fiksen $\varnothing$ (2008) The evolution of spawning migrations: state dependence and fishing-induced changes. Ecology 89:3436-3448

Kimura S, Kato Y, Kitagawa T, Yamaoka N (2010) Impacts of environmental variability and global warming scenario on Pacific bluefin tuna (Thunnus orientalis) spawning grounds and recruitment habitat. Prog Oceanogr 86: 39-44

Kitagawa T, Kato Y, Miller MJ, Sasai Y, Sasaki H, Kimura S (2010) The restricted spawning area and season of Pacific bluefin tuna facilitate use of nursery areas: a modeling approach to larval and juvenile dispersal processes. J Exp Mar Biol Ecol 393:23-31

Klawe WL (1963) Observations of the spawning of four species of tuna (Neothunnus macropterus, Katsuwonus pelamis, Auxis thazard and Euthynnus lineatus) in the eastern Pacific Ocean, based on the distribution of their larvae and juveniles. Inter-Am Trop Tuna Comm Bull 6: 449-540

> López-Jurado JL, Marcos M, Monserrat S (2008) Hydrographic conditions affecting two fishing grounds of Mallorca island (Western Mediterranean) during the IDEA project (2003-2004). J Mar Syst 71:303-315

Margulies D, Suter JM, Hunt SL, Olson RJ, Scholey VP, Wexler JB, Nakazawa A (2007) Spawning and early development of captive yellowfin tuna (Thunnus albacares). Fish Bull 105:249-265

> McGurk MD (1986) Natural mortality of marine pelagic fish eggs and larvae: role of spatial patchiness. Mar Ecol Prog Ser 34:227-242 
Medina A, Abascal FJ, Megina C, Garcia A (2002) Stereological assessment of the reproductive status of female Atlantic northern bluefin tuna during migration to Mediterranean spawning grounds through the Strait of Gibraltar. J Fish Biol 60:203-217

Medina A, Abascal FJ, Aragón L, Mourente G and others (2007) Influence of sampling gear in assessment of reproductive parameters for bluefin tuna in the western Mediterranean. Mar Ecol Prog Ser 337:221-230

Morote E, Olivar MP, Pankhurst PM, Villate F, Uriarte M (2008) Trophic ecology of bullet tuna Auxis rochei larvae and ontogeny of feeding-related organs. Mar Ecol Prog Ser 353:243-254

Muhling BA, Lamkin JT, Roffer MA (2010) Predicting the occurrence of Atlantic bluefin tuna (Thunnus thynnus) larvae in the northern Gulf of Mexico: building a classification model from archival data. Fish Oceanogr 19: 526-539

Murua H, Saborido-Rey F (2003) Female reproductive strategies of marine fish species of the North Atlantic. J Northwest Atl Fish Sci 33:23-31

Nishikawa Y, Homma M, Ueyanagi S, Kikawa S (1985) Average distribution of larvae of oceanic species of scombroid fishes, 1956-1981. Far Seas Fish Lab 12(S Ser):1-99

Ramon D, Bailey K (1996) Spawning seasonality of albacore, Thunnus alalunga, in the south Pacific Ocean. Fish Bull 69:555-568

Reglero P, Urtizberea A, Torres AP, Alemany F, Fiksen $\varnothing$ (2011) Cannibalism among size classes of larvae may be a substantial mortality component in tuna. Mar Ecol Prog Ser 433:205-219

Rooker JR, Bremer JRA, Block BA, Dewar H and others

Editorial responsibility: Stylianos Somarakis, Heraklion, Greece
(2007) Life history and stock structure of Atlantic bluefin tuna (Thunnus thynnus). Rev Fish Sci 15:265-310

Rooker JR, Secor DH, DeMetrio G, Kaufman AJ, Rios AB, Ticina V (2008) Evidence of trans-Atlantic movement and natal homing of bluefin tuna from stable isotopes in otoliths. Mar Ecol Prog Ser 368:231-239

Sabatés A, Recasens L (2001) Seasonal distribution and spawning of small tunas (Auxis rochei and Sarda sarda) in the northwestern Mediterranean. Sci Mar 65: 95-100

Saber S, Gómez-Vives MJ, Báez JC, Godoy D, Macías D (2011) Estimating batch fecundity of the Mediterranean albacore. A comparison between quantification of postvitellogenic follicles and postovulatory follicles. Collect Vol Sci Pap ICCAT 66:1919-1930

Satoh K (2010) Horizontal and vertical distribution of larvae of Pacific bluefin tuna Thunnus orientalis in patches entrained in mesoscale eddies. Mar Ecol Prog Ser 404: $227-240$

Sharp GD (2001) Tuna oceanography - an applied science. In: Block BA, Stevens ED (eds) Tuna: physiology, ecology and evolution. Academic Press, London, p 345-389

$>$ Teo SLH, Boustany AM, Block BA (2007) Oceanographic preferences of Atlantic bluefin tuna, Thunnus thynnus, on their Gulf of Mexico breeding grounds. Mar Biol 152: 1105-1119

Torres AP, Reglero P, Balbín R, Urtizberea A, Alemany F (2011) Coexistence of larvae of tuna species and other fish in the surface mixed layer in the NW Mediterranean. J Plankton Res 33:1793-1812

Wood SN (2006) Generalized additive models, an introduction with R. Chapman \& Hall, London

Submitted: February 2, 2012; Accepted: May 4, 2012

Proofs received from author(s): August 17, 2012 